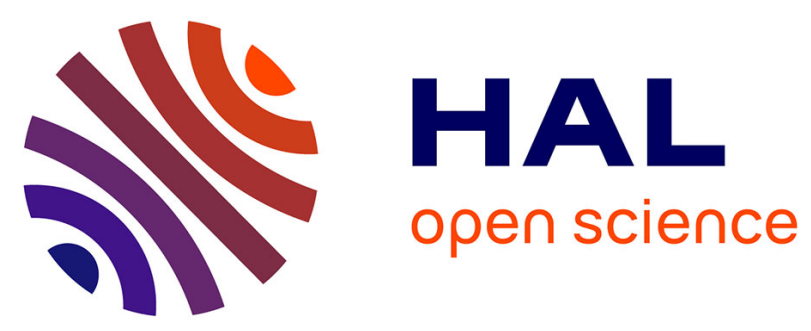

\title{
New electron donor in planar heterojunction: optimization of the cells efficiency through the choice of the hole-extracting layer
}

\author{
Pedro Zamora, Belkacem Kouskoussa, Zouhair El Jouad, Kada El Assad \\ Zemallach Ouari, Kheireddine Benchouk, Khedidja Benameur, Jean Christian \\ Bernède, Linda Cattin
}

\section{To cite this version:}

Pedro Zamora, Belkacem Kouskoussa, Zouhair El Jouad, Kada El Assad Zemallach Ouari, Kheireddine Benchouk, et al.. New electron donor in planar heterojunction: optimization of the cells efficiency through the choice of the hole-extracting layer . European Physical Journal: Applied Physics, 2020, 89 (2), pp.20201. 10.1051/epjap/2020190346 . hal-02586549

\author{
HAL Id: hal-02586549 \\ https://hal.science/hal-02586549
}

Submitted on 15 May 2020

HAL is a multi-disciplinary open access archive for the deposit and dissemination of scientific research documents, whether they are published or not. The documents may come from teaching and research institutions in France or abroad, or from public or private research centers.
L'archive ouverte pluridisciplinaire HAL, est destinée au dépôt et à la diffusion de documents scientifiques de niveau recherche, publiés ou non, émanant des établissements d'enseignement et de recherche français ou étrangers, des laboratoires publics ou privés. 


\title{
New electron donor in planar heterojunction: optimization of the cells efficiency through the choice of the hole-extracting layer ${ }^{\star}$
}

Pedro Zamora ${ }^{1}$, Belkacem Kouskoussa ${ }^{2}$, Zouhair El Jouad ${ }^{3}$, Kada El Assad Zemallach Ouari ${ }^{2}$, Kheireddine Benchouk ${ }^{2,}$, Khedidja Benameur ${ }^{2}$, Jean Christian Bernède ${ }^{3}$, and Linda Cattin ${ }^{4}$

${ }^{1}$ Laboratorio de síntesis Química, Departamento de Química y Biología, Facultad de Ciencias Naturales, Universidad de Atacama Copayapu, 485 Copiapó, Chile

${ }^{2}$ Université Oran1 - Ahmed Ben Bella, LPCMME, BP 1524 ELM Naouer, 31000 Oran, Algerie

3 MOLTECH-Anjou, CNRS, UMR 6200, Université de Nantes, 2 rue de la Houssinière, BP 92208, Nantes 44000, France

${ }^{4}$ Institut des Matériaux Jean Rouxel (IMN), CNRS, UMR 6502, Université de Nantes, 2 rue de la Houssinière, BP 32229,44322 Nantes cedex 3, France

Received: 5 December 2019 / Received in final form: 15 February 2020 / Accepted: 2 March 2020

\begin{abstract}
Due to their light weight, flexibility and semi-transparency the organic photovoltaic cells play an important role for solar conversion photovoltaic (OPV). To achieve good performances, both donor and acceptor materials in OPVs need to have good extinction coefficients, high stabilities and good film morphologies. Since the donor plays a critical role as the absorber to solar photon flux, donor materials require wide optical absorption to match the solar spectrum. In this work the couple ED/EA in planar heterojunction was Tetracyano 4,4'-bis $\left(9 H\right.$ carbazol-9-yl) biphenyl (TCC)/fullerene $\left(\mathrm{C}_{60}\right)$. Optimum results are obtained when $\mathrm{MoO}_{3}$ alone is used as Hole Transporting Layer (HTL). The J/V characteristics do not exhibit S-shaped curves up to a TCC layer thickness of $15 \mathrm{~nm}$, while they did when the HTL includes CuI. Theoretical study, complementary to the experimental study, shows that in the case of S-shaped curve the cell behaves as if it was made up of 2 diodes, one of which would be opposed to the flow of the photogenerated current. In the case of $\mathrm{MoO}_{3} \mathrm{HTL}$, i.e; without shaped curve, the optimum thickness is $13 \mathrm{~nm}$, giving an efficiency $\eta=2.30 \%$ with $V_{\mathrm{oc}}=0.9 \mathrm{~V}, J_{\mathrm{sc}}=5.17 \mathrm{~mA} / \mathrm{cm}^{2}$ and $\mathrm{FF}=49 \%$.
\end{abstract}

\section{Introduction}

A great interest is dedicated to organic photovoltaic Cells (OPVs) due to their low weight and flexibility. OPVs are based on an organic couple electron donor/electron acceptor, (ED)/(EA). The mains parameters on which the OPV efficiency depends are the open circuit voltage, $V_{\text {oc }}$, the short circuit current, $J_{s c}$ and the fill factor, FF [1]. The $V_{\text {oc }}$ maximum value is limited by the difference between the Lowest Occupied Molecular Orbital of the acceptor $\left(\mathrm{LUMO}_{\mathrm{A}}\right)$ and the Highest Occupied Molecular Orbital of the donor $\left(\mathrm{HOMO}_{\mathrm{D}}\right.$ ) [2]. If $V_{\mathrm{oc}}$ increases with $\Delta\left(\mathrm{LUMO}_{\mathrm{A}}-\mathrm{HOMO}_{\mathrm{D}}\right)$, the light absorption efficiency depends on the band gap value, Eg. The optimum band gap value is: $1.5 \mathrm{eV}<E g<2 \mathrm{eV}$. Moreover, the energy difference between the LUMOs (and HOMOs) of the donor and acceptor must be higher than the exciton energy, in order to achieve efficient charge separation. Therefore it is necessary to find the optimum compromise, to achieve the highest possible efficiency. In the present study, in order to

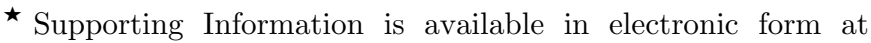
https://www.epjap.org/10.1051/epjap/2020190346

* e-mail: kbenchouk08@gmail.com
}

obtain easily reproducible experimental conditions, we choose to work on planar-heterojunctions (PHJ) deposited under vacuum. Actually, if, often, OPVs based on bulkheterojunction (BHJ) achieve highest efficiency, their morphology is difficult to control. Therefore, we used simple stacked organic layers sandwiched between an ITO anode and an Al cathode. We used fullerene as acceptor, while we used a new electron donor. Donor-acceptor molecules have attracted particular attention, due to their low band gap and charge transport properties. In the present work, a new donor with four cyano groups is synthesized in order to study the effect relationship between photoelectrical properties and the electron-withdrawing effect of these cyano groups. For this reason we report how the introduction of four cyano groups in a carbazole derivative molecule (Tetracyano 4,4'-bis(9Hcarbazol-9-yl) biphenyl (TCC)) can change their behaviour in OPVs.

\section{Experimental}

\subsection{Chemical synthesis and characterization of tetracyano 4,4'-bis(9H-carbazol-9-yl)biphenyl) (TCC)}

2,7 dicyanocarbazole (6 mmol.), $\mathrm{K}_{2} \mathrm{CO}_{3}$ (8 mmol), $\mathrm{CuI}$ $(2 \mathrm{mmol})$, were placed into a tube with anydrous DMF 


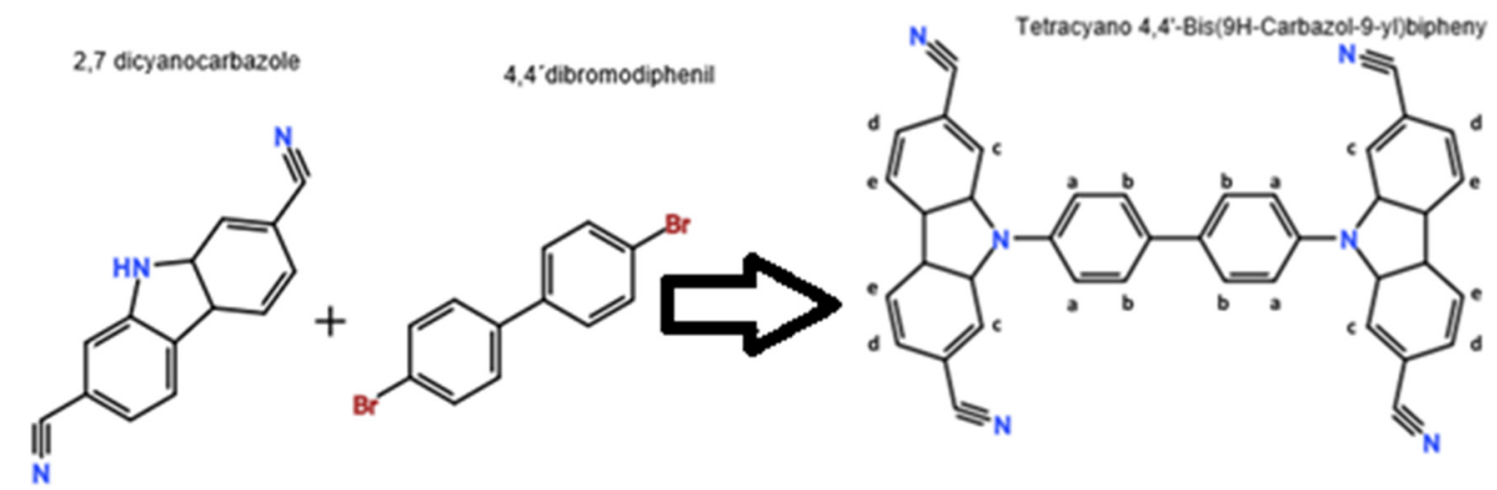

Scheme 1. Synthesis of Tetracyano 4,4'- bis(9Hcarbazol-9-yl)biphenyl (TCC) (TCC with protons assignment).

$(13 \mathrm{~mL})$. The solution was degassed for $30 \mathrm{~min}$ under stirring. $4,4^{\prime}$ dibromodiphenyl $(1.3 \mathrm{mmol})$ was charged to the solution of 2,7 dicyanocarbazole. The resulting solution was heated to $120^{\circ} \mathrm{C}$ for $24 \mathrm{~h}$ by the use of silicone bath under nitrogen. The progress of the reaction was checked by TLC (Thin-layer chromatography) until the substrate was completely consume. After cooling down to room temperature, the mixture was poured onto water. The aqueous layer was separated off, and the organic layer was concentrated under reduced pressure to give solid residue. The residue was dissolved in toluene, and the solution was decolorized by silica gel $(1 \mathrm{~g})$ and filtered with filter paper. The filtrate was concentrated under reduced pressure to give the solid, which was re-crystallized from toluene/ methanol. Isolated yield: $52.3 \%$ (Scheme 1).

TCC was characterized using ${ }^{1} \mathrm{H}-\mathrm{NMR}$. The ${ }^{1} \mathrm{H}-\mathrm{NMR}$ spectra was recorded on a Bruker $400 \mathrm{MHz}$ spectrophotometer using $\mathrm{CDCl}_{3}$ as solvent to determine the chemical structure.

The electrochemical study was performed on a Voltamaster model CV 50W potenciostat/galvanostat, using a conventional three-compartment, three-electrode cell, and a polycrystalline platinum disk $\left(0.07 \mathrm{~cm}^{2}\right.$ geometric area $)$ as working electrode. The counter electrode was a coiled Pt wire of large area, separated from the electrolytic solution by a sintered glass. The reference electrode was an $\mathrm{Ag} /$ $\mathrm{AgCl}$ electrode that matches the potential of the saturated calomel electrode (SCE). Then all potentials quoted in the electrochemical section, are referred to the SCE. The voltammogram of TCC $\left(0.01 \mathrm{~mol} \cdot \mathrm{l}^{-1}\right)$ was carried out in anhydrous acetonitrile using tetrabutylammonium hexafluorophosphate (TBAPF6, $0.1 \mathrm{~mol} \mathrm{l^{-1 }}$ ) as supporting electrolyte. All the system was kept under argon atmosphere and all measurements were performed at room temperature.

The cyclic voltammetry allows estimating the HOMO and LUMO values. To estimate the HOMO and LUMO energy, the slope change of the anodic and cathodic current were determined. These values corresponds to the onset oxidation potential (Eox)on, and onset reduction potential (Ered)on and correlates linearly with the HOMO and LUMO energy, with a correction factor of $4.4 \mathrm{eV}$ [3-10]

$$
\begin{aligned}
& \left.\mathrm{E}_{\mathrm{HOMO}}=-\left(\mathrm{E}_{\mathrm{ox}}\right)_{\text {on }}+4.4\right) \mathrm{eV} \\
& \left.\mathrm{E}_{\mathrm{LUMO}}=-\left(\mathrm{E}_{\mathrm{red}}\right)_{\text {on }}+4.4\right) \mathrm{eV} .
\end{aligned}
$$

The different characterizations, XRD (X-ray diffraction), SEM (scanning electron microscopy), OD (optical density) and cyclic voltammetry are presented in the Supporting information S1.

\subsection{Theoretical calculation of UV-vis spectrum of TCC}

In this work, we performed theoretical calculations to predict the UV-vis spectrum and in this way understand the electronic structure of TCC and if the $E g$ is adequate. The Tauc equation was used to predict the band gap of TCC. The calculated UV-vis spectrum can show us how the theoretical protocols could help in the understanding of electronic structure and in the prediction of relevant properties which can accelerate the synthesis process of new molecules. All calculations were based on the Density Functional Theory [11,12] using the computational package Gaussian03 [13]. Geometry optimizations were done using the hybrid exchange-correlation B3LYP17-19 functional, combined with the triple split-valence basis set and polarization functions $6-311 \mathrm{G}(\mathrm{d}, \mathrm{p})$. The selection of this level of theory was based on a previous study done by Duarte et al. [14] of the potential energy surface of $2 \mathrm{Th}$, where several density functionals as well as CCSD (coupled-cluster with single and double excitations) and MP4(SDQ) (fourth order Møller-Plesset perturbation theory, neglecting triple excitations) where selected. Regarding the structural predictions they found that the B3LYP/6311G(d,p) and MP2/cc-pVDZ fully optimized geometries exhibit the best agreement with the gas phase electron diffraction data, and concluded that DFT/ $6-311 \mathrm{G}^{* *}$ calculations were the most computationally efficient procedure. Frequency calculations of all optimized structures were performed to confirm the nature of the stationary points. An unrestricted calculation scheme was applied for the neutral structure of TCC.

\subsection{Organic photovoltaic cells realization and characterization}

Substrate preparation and the organic photovoltaic cells realization were already described [15] and are briefly recalled in the supporting information S2. The couple $\mathrm{ED} / \mathrm{EA}$ in the binary planar heterojunction was 
Tetracyano 4,4'- bis(9Hcarbazol-9-yl)biphenyl/fullerene $\left(\mathrm{C}_{60}\right)$.

Hole and electron extracting layers are desirable to improve the power conversion efficiency (PCE) of the OPVs, the hole transporting layer (HTL) inserted between the ITO anode and TCC was a double layer $\mathrm{MoO}_{3} / \mathrm{CuI}[16,17]$. On the other hand, an exciton blocking layer (EBL) was inserted between the $\mathrm{C}_{60}$ and the $\mathrm{Al}$ cathode. The EBL was a tris-(8-hydroxyquinoline) aluminium $\left(\mathrm{Alq}_{3}\right.$ ) layer. $\mathrm{Alq}_{3}$ was chosen because it was shown that it allows growing solar cells with higher lifetime, moreover it has been proven to be a very efficient exciton buffer layer. Finally, the structures used were as follow:

Glass/ITO $(100 \mathrm{~nm}) / \mathrm{MoO}_{3}(3 \mathrm{~nm}) / \mathrm{CuI}(1.5$ or $0 \mathrm{~nm}) /$ $\mathrm{TCC}(\mathrm{x} \mathrm{nm}) / \mathrm{C}_{60}(45 \mathrm{~nm}) / \mathrm{Alq}_{3}(9 \mathrm{~nm}) / \mathrm{Al}(120 \mathrm{~nm})$, the thickness $\mathrm{x}$ of TCC was used as parameter.

Electrical characterizations were performed with an automated $I-V$ tester, in the dark and under sun global AM 1.5 simulated solar illumination. Performances of photovoltaic cells were measured using a calibrated solar simulator (Oriel $300 \mathrm{~W}$ ) at $100 \mathrm{~mW} / \mathrm{cm}^{2}$ light intensity. Measurements were performed at an ambient atmosphere. All devices were illuminated through TCO electrodes.

The series resistance $(R s)$ and the shunt resistance $\left(R_{\mathrm{sh}}\right)$ were estimated using the $J-V$ characteristics, through the slopes at the open circuit voltage point and at the short circuit point respectively.

\section{Experimental results}

\subsection{Characterization of the TCC}

The 1H-NMR spectrum of TCC is summarized below: $\left(400 \mathrm{MHz}, \mathrm{CDCl}_{3}\right)$ 1H-NMR: $\delta 7.86(4 \mathrm{H} \mathrm{d}, J=6.5 \mathrm{~Hz})$, $\delta 8.29(4 \mathrm{H}, \mathrm{dd}, J=5.0,1.4 \mathrm{~Hz}), \delta 8.35(4 \mathrm{H} \mathrm{d}, J=6.5 \mathrm{~Hz})$, $8.54(4 \mathrm{H}, \mathrm{dd}, J=5.0,0.5 \mathrm{~Hz}), 88.59(4 \mathrm{H}, \mathrm{dd}, J=1.4$, $0.5 \mathrm{~Hz})$.

Before to start the analysis of the H-NMR spectrum, it must be noted that the molecule has a plane of symmetry which produces symmetrical protons with identical magnetic characteristics. In this case the same magnetic protons have the same letter (Schemes 1 and S5).

The chemical shifts, $\delta$, and couplings, $J$, of the protons are consistent with the experimental results. In the case of protons $\mathrm{d}$ and e they present double signals strongly coupled to each other at $5.02 \mathrm{~Hz}$ indicating that they are in neighboring positions (orto positions). The protons e also have a weak coupling of $0.53-0.55 \mathrm{~Hz}$ with the protons $\mathrm{c}$. This indicated they are in far positions within the aromatic system. (para position). In the same way, protons c have coupling of $1.43 \mathrm{~Hz}$ with proton d. (they are closer than c and e protons) (meta position). Protons $\mathrm{c}$ and $\mathrm{d}$ are separated by a nitril group and therefore there is not hydrogen in that position. In this sense it is only possible to see one coupling between $\mathrm{c}$ and $\mathrm{d}$. The protons $\mathrm{c}, \mathrm{d}$ and $\mathrm{e}$ have each ones two couplings indicating that there are only three protons in each aromatic ring in nearby positions separated by a nitrile group (supplementary information S5.

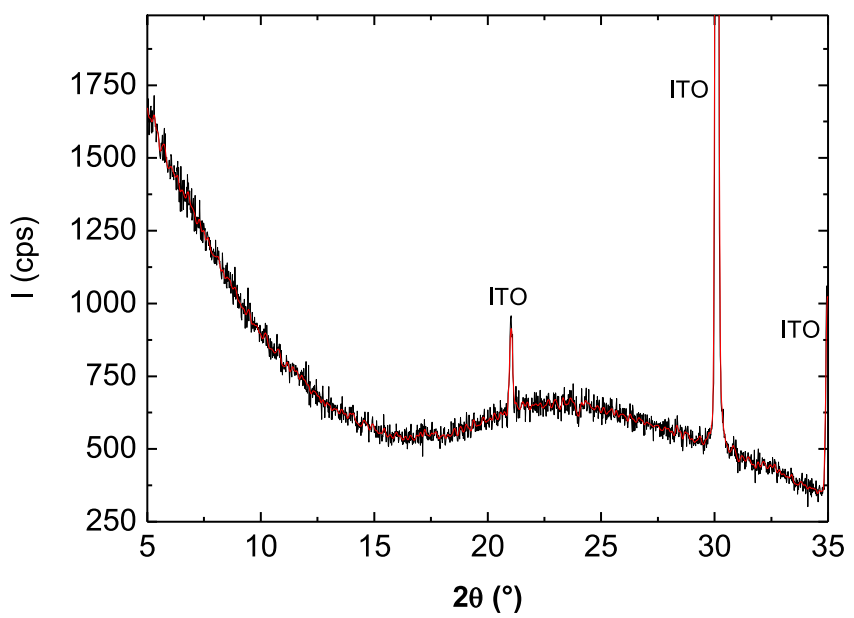

Fig. 1. X-ray diffraction diagram of $\mathrm{ITO} / \mathrm{MoO}_{3} / \mathrm{CuI} / \mathrm{TTC}$.

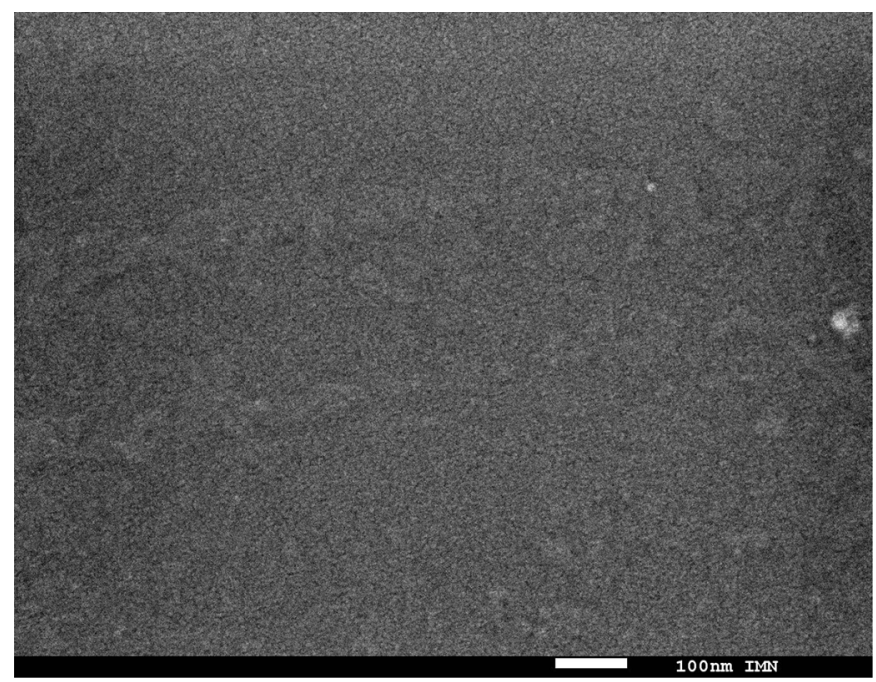

Fig. 2. Surface visualization of a structure $\mathrm{ITO} / \mathrm{MoO}_{3} \mathrm{CuI} /$ TCC.

Protons a and b present doublet signals strongly coupled at $6.50 \mathrm{~Hz}$. This fact indicates that they are in a neighboring position (orto position).

\subsection{Characterization of the TCC thin films}

The XRD pattern of ITO $/ \mathrm{MoO}_{3} / \mathrm{CuI} / \mathrm{TCC}$ (Fig. 1 ), exhibits different diffraction peaks, which are due to ITO. No peaks due to TCC are visible which means that the ED layer is amorphous.

The surface visualization of ITO $/ \mathrm{MoO}_{3} / \mathrm{CuI} / \mathrm{TCC}$ is visualized in Figure 2. It can be seen that the TCC layer is highly homogeneous.

Optical absorption curves are reported in Figure 3. Figure 3a shows the experimental spectrum obtained for an ITO $/ \mathrm{MoO} 3 / \mathrm{CuI} / \mathrm{TCC}$ structure, while the Figure 3b presents the theoretical curve. It can be seen that the 

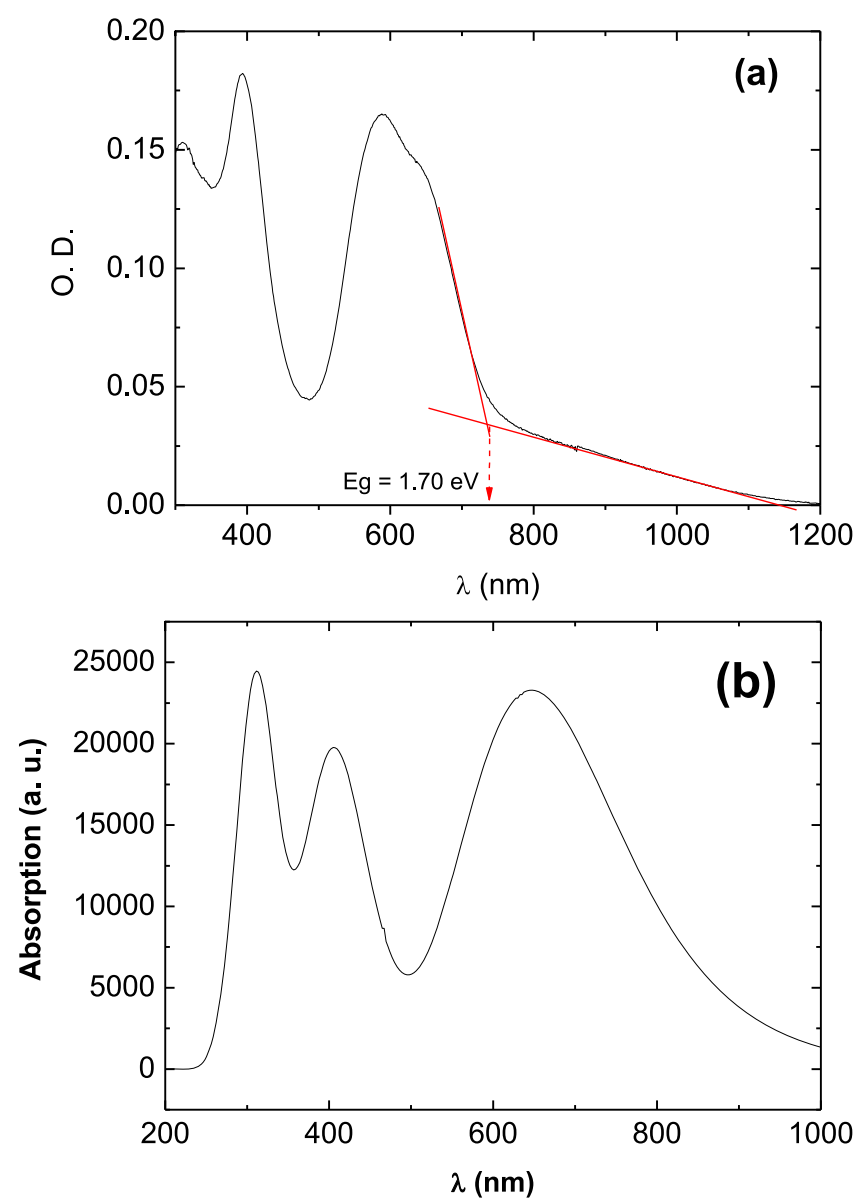

Fig. 3. (a) Optical density of a structure $\mathrm{ITO} / \mathrm{MoO}_{3} / \mathrm{CuI} / \mathrm{TCC}$; (b) "theoretical absorption of TCC".

shape of both spectra are quite similar, which shows that there is no destruction of the molecule during TCC sublimation. The optical band gap deduced from the experimental spectrum (Fig. 3a) is estimated to $1.70 \mathrm{eV}$.

The HOMO and LUMO levels were obtained experimentally from the cyclic voltammetry study. The electrochemical band gap was calculated using the difference between the electrochemical HOMO and LUMO obtained [18]. The optical $E g$ is in agreement with the electrochemical and theoretical band gap but with the difference that charge transport in $\mathrm{CV}$ is coupled to mass transfer while in optical measurements only electron movement is necessary $[19,20]$.

Geometry of the molecules deposited on the platinum electrode is similar to that in solution, When the $E g$ is determined by UV-vis in solid state, after deposition by high vacuum sublimation the molecular geometry changes. By other hand in theoretical calculations a phase gas is considered and a little difference between optical, elecrochemical and theoretical $E g$ can be observed Table 1.

Molecular geometry is very important to obtain desired values for $E g$ because it plays a decisive role for the conjugation of the $\pi$-system on the molecule backbone [21]. Thus changes of the geometry will affect also the
Table 1. TCC parameters determined by cyclic voltammetry and optical measurements (*Averaged value).

\begin{tabular}{lllll}
\hline Molecule & $\begin{array}{l}\text { HOMO } \\
(\mathrm{eV})\end{array}$ & $\begin{array}{l}\text { LUMO } \\
(\mathrm{eV})\end{array}$ & $\begin{array}{l}E g \\
(\text { electrochemical })\end{array}$ & $\begin{array}{l}E g \\
\text { (optical) }\end{array}$ \\
\hline TCC & -5.3 & -3.8 & $1.7^{*}$ & 1.7 \\
\hline
\end{tabular}

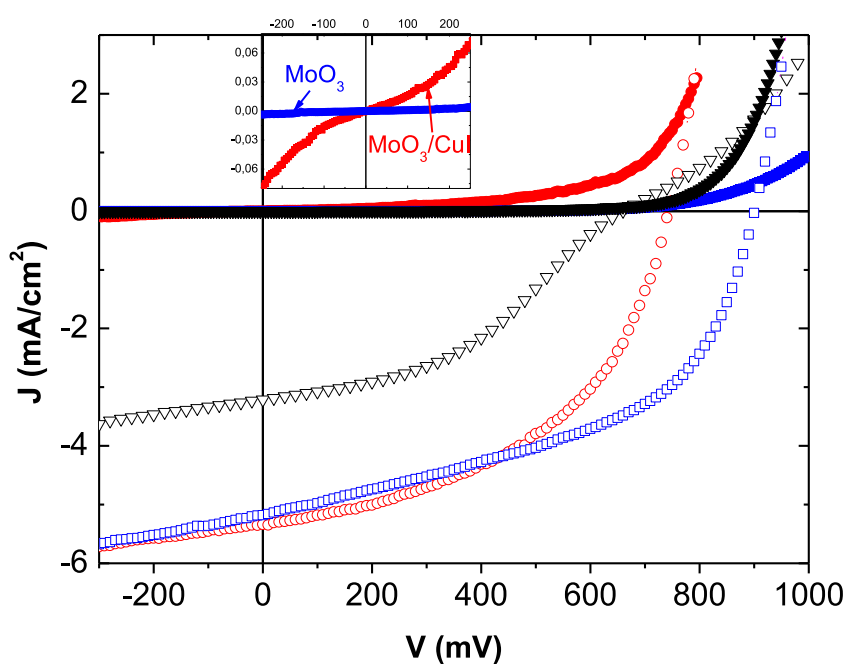

Fig. 4. Typical $J-V$ characteristics of OPVs: $\mathbf{\nabla}-\mathrm{ITO} / \mathrm{MoO}_{3}$ $(3 \mathrm{~nm}) / \mathrm{CuI}(1.5 \mathrm{~nm}) / \mathrm{TCC}(20 \mathrm{~nm}) / \mathrm{C}_{60} / \mathrm{Alq}_{3} / \mathrm{Al}, \bigcirc-\mathrm{ITO} /$ $\mathrm{MoO}_{3}(3 \mathrm{~nm}) / \mathrm{CuI}(1.5 \mathrm{~nm}) / \mathrm{TCC}(13 \mathrm{~nm}) / \mathrm{C}_{60} / \mathrm{Alq}_{3} / \mathrm{Al}, \mathbf{\square}-$ ITO $/ \mathrm{MoO}_{3}(3 \mathrm{~nm}) / \mathrm{TCC}(13 \mathrm{~nm}) / \mathrm{C}_{60} / \mathrm{Alq}_{3} / \mathrm{Al}$ (the filled symbols correspond to dark conditions while the open symbols correspond to light AM 1.5 conditions). Inset Figure 4: Dark current.

conjugation and in consequence the $E g$ energy. These geometries are different in solid state (OD) solution (CV) and gas phase (theoretical).

\subsection{Characterization of PHJ-OPVs based on the couple $\mathrm{TCC} / \mathrm{C}_{60}$}

Typical $J-V$ characteristics are presented in Figure 4, while the results are summarized in Table 2 . The thickness of the TCC layer was used as parameter.

It can be seen from Figure 4 that the shape of the curves depends on the TCC layer thickness and of the HTL. Table 2 presents a summary of the results obtained. Values reported in Table 2 correspond to the average values obtained for series of 6 cells. The deducted incertitude on the different parameters is given in Table 2. Even if the uncertainty is not negligible, the averaged values obtained indicate that the optimum thickness of TCC is around $13 \mathrm{~nm}$. In the case of $\mathrm{MoO}_{3} / \mathrm{CuI} \mathrm{HTL}$, for higher thickness the $J-V$ characteristics exhibit an S-shaped curve, while for thinner films FF decreases very significantly. It must be noted that there is no S-shaped curve in the dark. When $\mathrm{MoO}_{3}$ alone is used as HTL, better results are obtained, the characteristics do not exhibit S-shaped curves up to a TCC 
Table 2. Variation of the parameters of the OPVs with the thickness of TCC.

\begin{tabular}{|c|c|c|c|c|c|c|c|}
\hline $\begin{array}{l}\text { TCC layer } \\
\text { thickness (nm) }\end{array}$ & $V_{\mathrm{oc}}(\mathrm{V})$ & $J_{\mathrm{sc}}\left(\mathrm{mA} / \mathrm{cm}^{2}\right)$ & $\mathrm{FF}(\%)$ & $\eta(\%)$ & $R s(\Omega)$ & $R_{\mathrm{sh}}(\Omega)$ & S-shape \\
\hline \multicolumn{8}{|c|}{ HTL: $\mathrm{MoO}_{3}(3 \mathrm{~nm}) / \mathrm{CuI}(1.5 \mathrm{~nm})$} \\
\hline 20 & $0.66 \pm 0.02$ & $3.21 \pm 0.45$ & $41 \pm 3$ & $0.86 \pm 0.45$ & 135 & 800 & Yes \\
\hline 18 & $0.69 \pm 0.01$ & $5.06 \pm 0.40$ & $35 \pm 2$ & $1.22 \pm 0.35$ & 100 & 450 & Yes \\
\hline 16 & $0.75 \pm 0.02$ & $5.18 \pm 0.25$ & $36.5 \pm 1$ & $1.41 \pm 0.25$ & 180 & 400 & Yes \\
\hline 14 & $0.75 \pm 0.01$ & $6.04 \pm 0.15$ & $40.5 \pm 1$ & $1.83 \pm 0.25$ & 75 & 410 & Yes \\
\hline 13 & $\mathbf{0 . 7 5} \pm 0.01$ & $\mathbf{5 . 3 3} \pm 0.20$ & $48.5 \pm 1$ & $1.92 \pm 0.25$ & 36 & 1150 & No \\
\hline 12 & $0.61 \pm 0.02$ & $4.50 \pm 0.25$ & $37 \pm 2$ & $1.01 \pm 0.35$ & 13 & 300 & No \\
\hline \multicolumn{8}{|c|}{ HTL: $\mathrm{MoO}_{3}(3 \mathrm{~nm})$} \\
\hline 12 & $0.70 \pm 0.01$ & $4.53 \pm 0.30$ & $44 \pm 1$ & $1.39 \pm 0.35$ & 15 & 475 & No \\
\hline 13 & $\mathbf{0 . 9 0} \pm 0.01$ & $\mathbf{5 . 1 7} \pm 0.15$ & $49 \pm 1$ & $\mathbf{2 . 3 0} \pm 0.25$ & 17 & 575 & No \\
\hline 14 & $0.88 \pm 0.01$ & $4.89 \pm 0.25$ & $46 \pm 2$ & $1.98 \pm 0.25$ & 20 & 615 & No \\
\hline 15 & $0.84 \pm 0.02$ & $3.70 \pm 0.30$ & $45 \pm 3$ & $1.40 \pm 0.40$ & 24 & 660 & No \\
\hline
\end{tabular}

layer thickness of $15 \mathrm{~nm}$. The optimum thickness is here also $13 \mathrm{~nm}$, but a higher efficiency is achieved since we have $\eta=2.30 \%$ with $V_{\mathrm{oc}}=0.9 \mathrm{~V}, J_{\mathrm{sc}}=5.17 \mathrm{~mA} / \mathrm{xm}^{2}$ and $\mathrm{FF}=$ $49 \%$. The efficiency improvement is mainly due to the increase of $V_{\mathrm{oc}}$.

The inset of Figure 4 shows that the saturation current, $\mathrm{Js}$, of the OPVs is significantly higher in the case of the double $\mathrm{HTL} \mathrm{MoO}_{3} / \mathrm{CuI}$. Actually, when the applied voltage is $0.25 \mathrm{~V}$, in the dark, with $\mathrm{MoO}_{3} / \mathrm{CuI}$ as $\mathrm{HTL}$, $J s$ is 25 times that of OPVs with $\mathrm{MoO}_{3}$ HTL. In the case of $\mathrm{CuI}$, this high leakage current induces a significant limitation of $V_{\mathrm{oc}}$. With $\mathrm{MoO}_{3}$ alone $J s$ is significantly smaller and, as result, $V_{\text {oc }}$ increases. Indeed, it was shown that too high roughness of the anode has a negative effect on the $V_{\mathrm{oc}}$ value due to an increase of the leakage currents [22].

It is known that, the surface roughness of the $\mathrm{CuI}$ layers deposited under vacuum is quite high $[23,24]$. Here, due to its small hole mobility, the thickness of the ED layer must be small to avoid too high series resistance. Such thin layer thickness coupled with the surface roughness of the CuI layer may justify the quite high leakage current and smaller $V_{\mathrm{oc}}$.

In order to try to understand the different behaviour induced by the different HTL, we have compared the mobility of the TCC layer with and without CuI, by making Space Charge Limited Current study (SCLC) (Supporting information S3) $[25,26]$, using hole only devices. Hole only devices were as follow: ITO/HTL/ TCC $(120 \mathrm{~nm}) / \mathrm{MoO}_{3}(7 \mathrm{~nm}) / \mathrm{Al}$, with $\mathrm{HTL}=\mathrm{MoO}_{3}$ $(3 \mathrm{~nm}) / \mathrm{CuI}(1.5 \mathrm{~nm})$ or MoO3 $(3 \mathrm{~nm})$. The obtained results are $\mu h=6.5 \pm 210^{-7} \mathrm{~cm}^{2} / \mathrm{Vs}$ in the case of $\mathrm{MoO}_{3} / \mathrm{CuI}$ and $\mu h=3.5 \pm 210^{-7} \mathrm{~cm}^{2} / \mathrm{V}$ s in the case of CuI. Even if there is some uncertainty, it can be deduced from these estimations that the hole mobility in the TCC layers deposited onto $\mathrm{MoO}_{3}$ alone is higher than that of layers deposited on $\mathrm{MoO}_{3} / \mathrm{CuI}$.

It should be noted that, regardless of the effect of the buffer layer, this mobility is low, which justifies the fact that the maximum efficiency is obtained for a relatively low layer thickness.

\section{Discussion}

Firstly, we will discuss the results obtained with our usual $\mathrm{HTL}, \mathrm{MoO}_{3} / \mathrm{CuI}$. When the TCC is thick of only $12 \mathrm{~nm}$, the shunt resistance is only $R_{s h}=300 \Omega$, such small $R_{s h}$ value induces leakage currents and quite high saturation current values, Js, which justifies the small $\mathrm{FF}$ and $V_{\mathrm{oc}}$ values. At $V=-0.3 \mathrm{~V}, J_{s}=1.210^{-3} \mathrm{~mA} / \mathrm{cm}^{2}$. For TCC film thicker than $13 \mathrm{~nm}$, the $J-V$ characteristics are S-shaped. An equivalent circuit model could be helpful in understanding the behaviour of the OPVs. The classical equivalent circuit of solar cells consists of a photogenerator connected in parallel with a diode, while a series resistance, $R s$, and a shunt resistance, $R_{s h}$ (Supplementary information Fig. S4-1a) must be introduced to take into account the resistance of the organic materials and contact resistance $(R s)$ and the defaults present at the interface and possible charge carrier recombination $\left(R_{\mathrm{sh}}\right)$. For such solar cells the mathematical description of this circuit is given in supporting information S4. We have already shown that such electrical equivalent circuit fails to account for the S-shaped curves. Actually, we showed that such S-shaped curves can be theoretically fitted by introducing a second diode of opposite polarity [23,27], here also the mathematical description of this circuit is given in supporting information (Supplementary information Fig. S4-1b).

About S-shaped curves, a typical example of modelling is given in Figure 5, the TCC layer thickness being $20 \mathrm{~nm}$. In Figure 5a we can see that a good fit between experimental dark characteristics and the theoretical curve obtained using a classical one diode equivalent circuit model, which is due to the fact that in the dark, the $J-V$ characteristics do not present the S-shaped curve. However such agreement cannot be obtained for the characteristics 

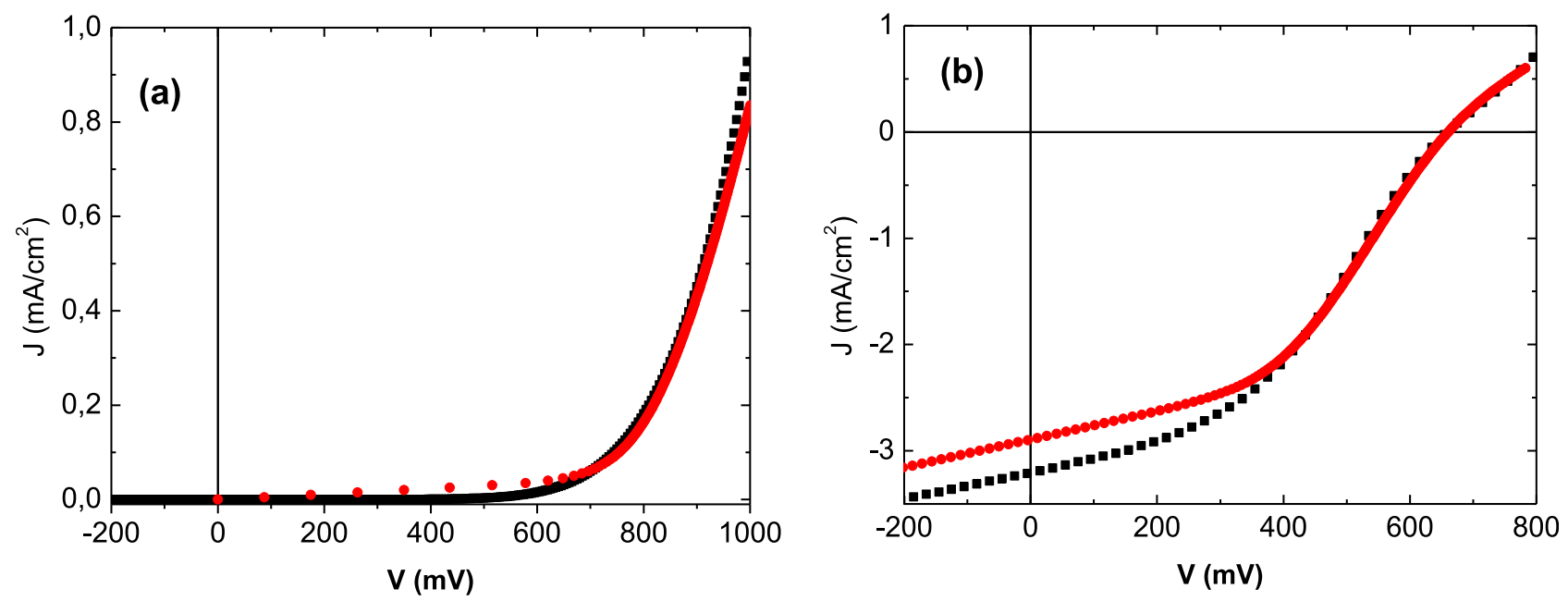

Fig. 5. $I-V$ characteristics in the dark (a) and under AM1.5 illumination of an OPV with 20 nm of TCC; ( $)$ experimental and $(\bullet)$ theoretical curves.

Table 3. Parameters calculated using a main diode and a back contact diode for different HTL and different layer thickness of the TCC.

\begin{tabular}{|c|c|c|c|c|c|c|c|c|}
\hline \multirow[t]{2}{*}{ HTL } & \multirow[t]{2}{*}{ TCC thickness (nm) } & \multicolumn{4}{|c|}{ Junction TCC $/ \mathrm{C}_{60}$} & \multicolumn{3}{|c|}{ Opposed diode } \\
\hline & & $n_{1}$ & $R_{\mathrm{sh}}(\Omega)$ & $R s(\Omega)$ & $J_{\mathrm{mo}}\left(\mathrm{A} / \mathrm{cm}^{2}\right)$ & $n_{2}$ & $R_{\mathrm{sh}}^{\mathrm{b}}(\Omega)$ & $J_{\mathrm{b} 0}\left(\mathrm{~A} / \mathrm{cm}^{2}\right)$ \\
\hline \multirow[t]{4}{*}{$\mathrm{MoO}_{3} / \mathrm{CuI}$} & $20 \mathrm{~nm}$ & 1.6 & 1350 & 56 & $2.610^{-10}$ & 1.3 & 220 & $2.410^{-4}$ \\
\hline & $18 \mathrm{~nm}$ & 1.4 & 700 & 48 & $1.610^{-9}$ & 1.3 & 115 & $2.410^{-4}$ \\
\hline & $14 \mathrm{~nm}$ & 1.7 & 380 & 40 & $1.410^{-10}$ & 1.3 & 70 & $2.410^{-4}$ \\
\hline & $12 \mathrm{~nm}$ & 1.7 & 240 & 6.6 & $1.910^{-9}$ & & & \\
\hline \multirow[t]{3}{*}{$\mathrm{MoO}_{3}$} & $15 \mathrm{~nm}$ & 1.8 & 600 & 10.7 & $1.710^{-11}$ & & & \\
\hline & $14 \mathrm{~nm}$ & 1.8 & 501 & 8.6 & $1.710^{-11}$ & & & \\
\hline & $12 \mathrm{~nm}$ & 1.8 & 400 & 6.6 & $1.710^{-11}$ & & & \\
\hline
\end{tabular}

obtained under illuminated conditions due to the fact that here the $J-V$ characteristics exhibit S-shaped curve. In that case, it can be seen in Figure $5 \mathrm{~b}$ and Table 1 that using the model with two diodes [28], a good agreement is obtained between the experimental and the theoretical curve. Similar agreement can be obtain for all OPVs exhibiting S-shaped curves under illumination. The obtained results are summarized in Table 3 . It can be seen that, with $\mathrm{MoO}_{3} /$ $\mathrm{CuI}$ as HTL, the series resistance increases strongly with the TCC layer thickness, which probably induces the apparition of the S-shaped curves.

When the TCC layer is thick of $12 \mathrm{~nm}$, the S-shaped curve does not appear even under illumination, which makes that it is not necessary to use the two diodes model. As a matter of fact, a good fit between experimental en theoretical curves is obtained using the single diode model. In the same way, but whatever the thickness of TCC, a single diode makes it possible to obtain a good agreement between the experimental curves and the theoretical curves in the case where the HTL is $\mathrm{MoO}_{3}$ alone (Fig. 6).
Therefore, while a very good agreement between the experimental and theoretical fitted curves is achieved when the HTL is $\mathrm{MoO}_{3}$ alone using the classical one diode model, this is no longer the case when the $\mathrm{HTL}$ is $\mathrm{MoO}_{3} / \mathrm{CuI}$, for a thickness of TTC greater than $12 \mathrm{~nm}$. The reasons for S-shaped curves are not evident. However two main explanations are usually provided. The S-shaped curve can be caused by the active material itself, here TCC, or by its interface to the electrode $[6,10]$. Low charge carrier mobilities, and more precisely, imbalanced mobilities can be at the origin of S-shaped curves [29]. We have shown that, in the present work, there is no S-shaped effect in the dark, which means that the S-shaped effect is due to photogenerated charge carriers [30]. Therefore, the Sshaped curve is probably caused by the active organic layer itself, i.e. the new ED, TCC, and its interaction with the HTL.

It is well known that hole mobility is smaller than electron mobility. In the case of planar heterojunctions, when the electron and hole mobility differ by more than 

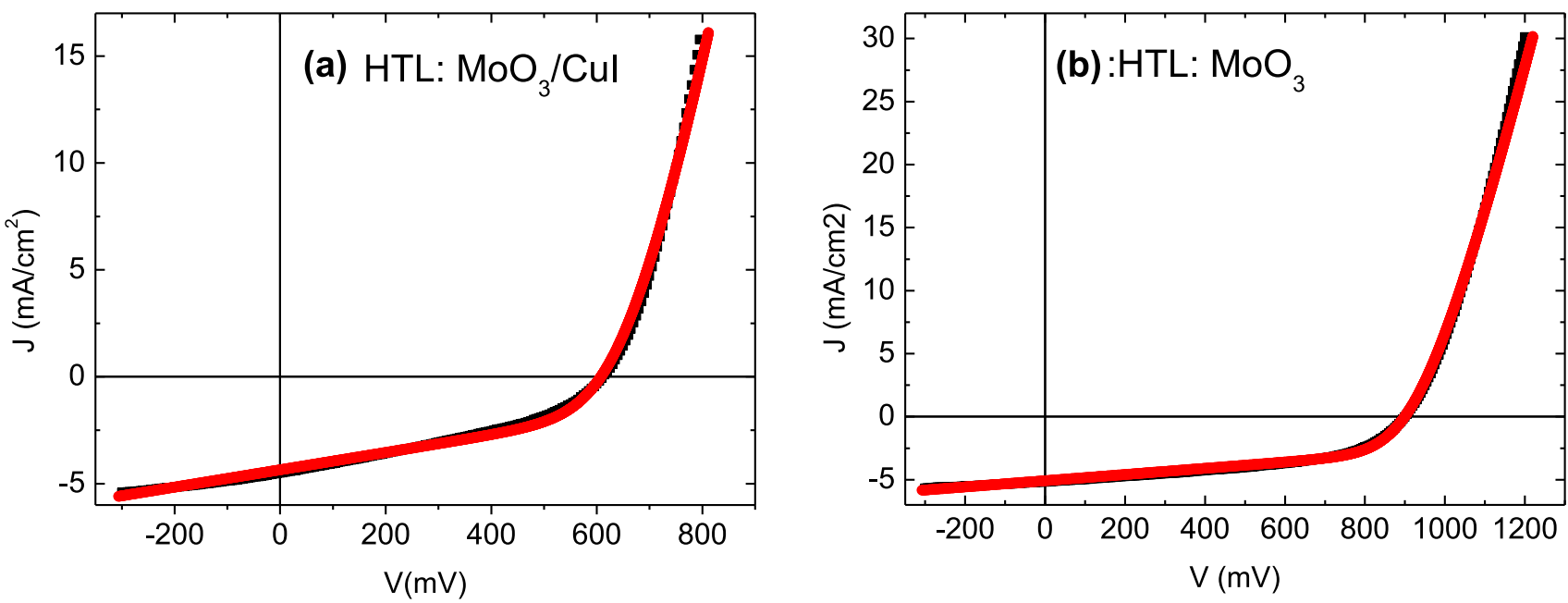

Fig. 6. $I-V$ characteristics under AM1.5 illumination of a OPVs with $13 \mathrm{~nm}$ of TCC and different $\mathrm{HTL}_{(\mathrm{a})} \mathrm{MoO}_{3} / \mathrm{CuI}_{\mathrm{I}}$ and (b) $\mathrm{MoO}_{3}$ alone; $(\square)$ experimental and $(\bullet)$ theoretical curves.

two order of magnitude, there is hole accumulation at the interface $\mathrm{ED} /$ electrode, which induces S-shaped $J-V$ characteristics [31]. In the present study, S-shaped effect in the $J-V$ characteristics vanished for the OPVs when the TCC layer thickness is small enough and with $\mathrm{MoO}_{3}$ as HTL. When the thickness of the resistive ED layer is significantly smaller than that of EA, the effect of the difference in electron and hole mobilities is counterbalanced by the difference in the thicknesses of the layers, difference which allows reducing the resistance imbalance, and there is no S-shaped curve. When the ED thickness increases, the hole accumulation is sufficient to induces S-shaped curves in the case of $\mathrm{MoO}_{3} / \mathrm{CuI} \mathrm{HTL}$, but not in the case of $\mathrm{MoO}_{3} \mathrm{HTL}$ (at least up to $15 \mathrm{~nm}$ ). It means that the undesirable S-shaped effect is probably due to the interaction between CuI and the TCC layer. As said above the S-shaped effect can be due to interface barrier and/or to unbalanced charge collection due to high difference in charge carrier mobility. Since the S-shaped effect is present only under light, a barrier, if present, is not permanent but created by photogenerated carriers. It was already shown that the presence of a bottom $\mathrm{CuI}$ thin layer has strong influence on the growth of organic layers. It can modify its optical absorption properties [32] and also its electrical properties $[15,33]$. In the present case, CuI has unfavourable impact on TCC properties, since it induces the Sshaped effect. As a matter of fact, it decreases the hole mobility in the TCC layer by comparison with MoO3 HTL. This effect may originate from difference in surface energy of the two HTL. We have shown that the surface energy $\Phi_{\mathrm{S}}$ of $\mathrm{CuI}\left(26,28 \mathrm{~mJ} / \mathrm{m}^{2}\right)$ is far smaller than that of $\mathrm{MoO}_{3}$ $\left(50.30 \mathrm{~mJ} / \mathrm{m}^{2}\right)$ [34]. It was shown that, in the case of pentacene for example, hole mobility depends significantly of the surface energy of the under layer [35]. Therefore, in the case of TCC, it appears that its carrier mobility decreases with the surface of the underlayer. Other phenomena may be proposed to justify the S-shape of the $J-V$ curves. For instance, since the S-shaped curve is present only under illumination, it is possible that the S-shaped curves originate from UV-spectrum. Actually, as proposed by Ajay K. Pandey et al. [36], surface states can be induced by UV at the interface organic material/ electrode.

\section{Conclusion}

The performances of planar heterojonction-OPVs with a TCC as a new ED are studied, the TCC thickness being used as parameter. When $\mathrm{MoO}_{3} / \mathrm{CuI}$ is used as HTL, the $\mathrm{J} / \mathrm{V}$ characteristics under illumination of these OPVs with different TCC layer thicknesses exhibit Sshaped curves up to a TCC layer thickness of $13 \mathrm{~nm}$. On the other hand, there is no S-shaped effect in the dark, which means that the S-shaped effect is due to photogenerated charge carriers. It means that there is hole accumulation at the interface $\mathrm{ED} /$ electrode, which induces S-shaped $J-V$ characteristics. When $\mathrm{MoO}_{3}$ alone is used as HTL, better results are obtained, the characteristics do not exhibit Sshaped curves up to a TCC layer thickness of $15 \mathrm{~nm}$, which means that $\mathrm{MoO}_{3}$ allows achieving a better contact with TCC than CuI. The optimum thickness is $13 \mathrm{~nm}$, the highest efficiency achieved is $\eta=2.30 \%$ with $V_{\mathrm{oc}}=0.9 \mathrm{~V}$, $J_{\mathrm{sc}}=5.17 \mathrm{~mA} / \mathrm{cm}^{2}$ and $\mathrm{FF}=49 \%$. The efficiency improvement is mainly due to the increase of $V_{\mathrm{oc}}$.

\section{Supplementary Material}

The Supplementary Material is available at https://www. epjap.org/10.1051/epjap/2020190346/olm.

We thank the Faculty of Natural Sciences of the University of Atacama for financial support (Incubacion 10/2018) and the Department of Chemistry and Biology for computational facilities. 


\section{Author contribution statement}

All authors participated equally in the published work: P. Zamora has synthesized and characterized organic molecules. Z. El Jouad, J.C. Bernède and L. Cattin have made and characterized the organic photovoltaic cells. B. Kouskoussa, K. El Assad Zemallach Ouari, K. Benameur and K. Benchouk have made the theoretical study.

\section{References}

1. J.C. Bernède, J. Chil. Chem. Soc. 53 (2008)

2. J.-C. Ke, Y.-H. Wang, K.-L. Chen, C.-J. Huang, Solar Energy Mater. Solar Cells 133, 248 (2015)

3. A. Charas, J. Morgado, J.M.G. Martinho, L. Alcácer, S.F. Lim, R.H. Friend, F. Cacialli, Polymer 44, 1843 (2003)

4. J. Pei, W.-L. Yu, J. Ni, Y.-H. Lai, W. Huang, A.J. Heeger, Macromolecules 34, 7241 (2001)

5. P.K. Hegde, A.V. Adhikari, M.G. Manjunatha, C.S. Sandeep Suchand, R. Philip, Synth. Met. 159, 1099 (2009)

6. Q. Zhang, Y. Li, M. Yang, J. Mater. Sci. 39, 6089 (2004)

7. A. Charas, J. Morgado, J.M.G. Martinho, L. Alcácer, S.F. Lim, R.H. Friend, F. Cacialli, Polymer 44, 1843 (2003)

8. S. Admassie, O. Inganäs, W. Mammo, E. Perzon, M.R. Andersson, Synth. Met. 156, 614 (2006)

9. P.K. Hegde, A.V. Adhikari, M.G. Manjunatha, C.S. Suchand Sandeep, R. Philip, Synth. Met. 159, 1099 (2009)

10. E. Zhou, M. Nakamura, T. Nishizawa, Y. Zhang, Q. Wei, K. Tajima, C. Yang, K. Hashimoto, Macromolecules 41, 8302 (2008)

11. P. Hohenberg, W. Kohn, Phys. Rev. B 136, 864 (1964)

12. W. Kohn, L.J. Sham, Phys. Rev. A 140, 1133 (1965)

13. Frisch et al., Gaussian 03, Revision C01 (Gaussian, Inc., Wallingford, 2004)

14. H.A. Duarte, H.F. Dos Santos, W.R. Rocha, W.B. De Almeida, J. Chem. Phys. 113, 4206 (2000)

15. Z. El Jouad, M. Morsli, G. Louarn, L. Cattin, M. Addou, J.C. Bernède, Sol. Energy Mater. Sol. Cells 141, 429 (2015)

16. J.C. de Bernè, L. Cattin, P. Predeep, Technol. Lett. 1, 2 (2014)

17. Y. Lare, B. Kouskoussa, K. Benchouk, S. Djobo Ouro, L. Cattin, M. Morsli, F.R. Diaz, M. Gacitua, T. Abachi, M.A. del Valle, F. Armijo, G.A. East, J.C. de Bernè, J. Phys. Chem. Solids 72, 97 (2011)
18. M. Ju Cho, J. Seo, Sol. Energy Mater. 98, 71 (2012)

19. C.L. Gaupp, K. Zong, P. Schottland, B.C. Thompson, C.A. Thomas, J.R. Reynolds, Macromolecules 33, 1132 (2000)

20. H.J. Ahonen, J. Lukkari, J. Kankare, Macromolecules 33, $6787(2000)$

21. P.P. Zamora, M.B. Camarada, I.A. Jessop, F.R. Díaz, G. Louarn, J.C. Bernede, Int. J. Electrochem. Sci. 7, 13 (2012)

22. F.Z. Dahou, L. Cattin, J. Garnier, J. Ouerfelli, M. Morsli, G. Louarn, A. Bouteville, A. Khelil, J.C. de Bernè, Thin Solid Films 518, 6117 (2010)

23. B. Kouskoussa, M. Morsli, K. Benchouk, G. Louarn, L. Cattin, A. Khelil, J.C. Bernède, Phys. Status Solidi A 206, $311(2009)$

24. J.-H. Lee, D.-S. Leem, J.-J. Kim, Org. Electron. 9, 805 (2008)

25. A.S. Yapi, L. Toumi, Y. Lare, G.M. Soto, L. Cattin, K. Toubal, A. Djafri, M. Morsli, A. Khelil, M.A. Del Valle, J.-C. Bernède, Eur. Phys. J. Appl. Phys. 50, 30403 (2010)

26. J.C. Blakesley et al., Org. Electron. 15, 1263 (2014)

27. K. El Assad Zemallach Ouari, Z. El Jouad, K. Benchouk, B. Kouskoussa, L. Cattin, M. Makha, A. Khelil, M. Morsli, M.J. C. Addou Bernède, Indian J. Pure Appl. Phys. 52, 829 (2014)

28. S.H. Demtsu, J.R. Sites, Thin Solid Films 510, 320 (2006)

29. W. Tress, A. Petrich, M. Hummert, M. Hein, K. Leo, M. Riede, Appl. Phys. Lett. 98, 063301 (2011)

30. X. Hao, S. Wang, W. Fu, T. Sakurai, S. Masuda, K. Akimoto, Org. Electron. 15, 1773 (2014)

31. L. Sims, U. Hörmann, R. Hanfland, R.C.I. MacKenzie, F.R. Kogler, R. Steim, W. Brütting, P. Schilinsky, Org. Electron. 15, 2862 (2014)

32. M. Makha, L. Cattin, Y. Lare, L. Barkat, M. Morsli, M. Addou, A. Khelil, J.C. de Bernè, Appl. Phys. Lett. 101, 233307 (2012)

33. M. Makha, L. Cattin, S. Dabos-Seignon, E. Arca, J. Velez, N. Stephant, M. Morsli, M. Addou, J.C. de Bernè, Appl. Phys. 51, $14(2013)$

34. J.C. de Bernè, L. Cattin, M. Makha, V. Jeux, P. Leriche, J. Roncali, V. Froger, M. Morsli, M. Addou, Sol. Energy Mater. Sol. Cells 110, 107 (2013)

35. S.Y. Yang, K. Shin, C.E. Park, Adv. Funct. Mater. 15, 1806 (2005)

36. A.K. Pandey, J.-M. Nunzi, H. Wang, C.C. Oey, A. B. Djurisic, M.H. Xie, Y.H. Leung, K.K.Y. Man, W.K. Chan, Org. Electron. 8, 396 (2007)

Cite this article as: Pedro Zamora, Belkacem Kouskoussa, Zouhair El Jouad, Kada El Assad Zemallach Ouari, Kheireddine Benchouk, Khedidja Benameur, Jean Christian Bernède, Linda Cattin, New electron donor in planar heterojunction: optimization of the cells efficiency through the choice of the hole-extracting layer, Eur. Phys. J. Appl. Phys. 89, 20201 (2020) 